\title{
A novel approach to teaching dermatology and plastic surgery in a combined module for undergraduate medical students
}

This article was published in the following Dove Press journal:

Advances in Medical Education and Practice

\author{
Hasan S Al-Ghamdi \\ Internal Medicine Department, Faculty of \\ Medicine, Albaha University, Al Bahah, \\ Saudi Arabia
}

Introduction:Medical students need to be equipped with the knowledge and skills to serve their communities properly. Interdisciplinary integration by merging similar disciplines together at the level of planning and implementation is a novel idea.

Objectives: The aim is to describe the methods and steps that were followed to plan and implement a module in dermatology and plastic surgery for the fifth year medical students of Albaha University Faculty of Medicine, to explain how two similar courses can be designed and merged into one module.

Methods: We followed the Kern's six steps for curriculum development in order to plan and implement the dermatology and plastic surgery module. Questionnaires were applied to measure the degree of both students and staff satisfactions about all Kern' steps of the dermatology-plastic surgery interdisciplinary course. Non-parametric $t$-test was used in the statistical results of Likert scale.

Results and discussion: According to these steps, the module committee identifies the problem and assesses the needs of the targeted learners. Then, goals and objectives of the module and educational strategies were determined. Finally, the evaluation and feedback were obtained from both faculty and students. Using a Likert scale to measure the degree of the satisfactions among students and staff for Kern'steps, no significant $P$-value was obtained for course evaluation steps, in contrast to the goals/objectives, educational strategies and implementation steps in which significant $P$-values were obtained.

Conclusion: Implementing Kern's methodology for curriculum development resulted in the integrated module of dermatology and plastic surgery with no major problems at all levels. Keywords: dermatology, interdisciplinary integration, plastic surgery, skin diseases, studentcentered

\section{Introduction}

It is not an acceptable concept nowadays to marginalize a discipline like dermatology by saying it a minor specialty. This concept reflected in the medical curricula by minimizing the time and activities allowed to teach dermatology. A survey in primary care residents in California in 2009, including internal medicine residents, showed that less than $40 \%$ of them think that their undergraduate medical curricula are adequately preparing them to diagnose and treat skin disorders. ${ }^{1}$ Knowing the basic dermatological problems should be a competence acquired by any practicing clinician. A study of inpatient dermatological consultations in 2010 in the US showed that nondermatologists inward doctors diagnose only $23.9 \%$ of the cases correctly. ${ }^{2}$ There is
Correspondence: Hasan S Al-Ghamdi Internal Medicine Department, Faculty of Medicine, Albaha University, PO Box 938, Alaqiq 22888, Kingdom of Saudi Arabia. Tel +9665330I3355

Email Dr.hasan33@hotmail.com 
a wide variation in the time allowed in medical schools for teaching dermatology. In a country like Canada, there is a medical school, which allowed an average of $20.5 \mathrm{hrs}$ for dermatology, whereas in the same country other schools allowed only $4 \mathrm{hrs}^{3}$ Such variations indicate that there is no solid rule set by the medical educationist for teaching dermatology for undergraduate medical students. The main goal for dermatology modules is to teach and train students to acquire skills and competencies which are required to practice dermatology at the level of community and other health system facilities. $^{4,5}$

Dermatological problems are a growing health system problem and the number of patients with skin diseases is increasing, this requires that medical school should adapt their curricula to equip their graduates with necessary theoretical and clinical competencies to deal with this issue. ${ }^{6,7}$

Medical students regrettably achieve limited experience to both dermatology and plastic surgery, usually within the fourth or fifth year of medical studies, but the length of exposure varies around the medical schools and ranging from 1 to 3 weeks. This time is not enough at all to acquire a solid knowledge of the dermatology. ${ }^{8-10}$

In addition, most of the dermatological problems are seen by non-dermatologists. ${ }^{3}$ This will necessitate that medical graduate or even those specialized in other disciplines is in need to be equipped with common clinical skills of dermatology. The number of patients is growing and the variety of the needs of the presenting clients are diverse. ${ }^{11}$ There are two aspects to be considered which make the need of teaching dermatology and plastic surgery for undergraduate medical students in Saudi Arabia is a priority. The first is growing number of skin cancer patients, a problem that needs both specialties in different levels of diagnosis, treatment and management of late complications. ${ }^{12}$ The second is the increasing number of patients who presented with skin problems and cosmetic management. Saudi Arabia is the first in the Middle East in this matter. ${ }^{13}$ Also, this reflected in the growing of the cosmetics market. ${ }^{14}$ Matching these needs with graduates' feedback is not possible in ABSM because of the novelty of the college and yet only two batches are graduating and they are in their first steps.

Plastic surgery is growing, and many factors are involved in this rapid development such as social, economic development, changes in cultural norms. Cultural changes and developments in different societies have increased concern and subsequently, these in addition to psychological factors give rise to increase the needs for plastic surgeries by people. ${ }^{15,16}$
Plastic surgery is a distinctive branch of surgery in that its borders are not clearly defined by age, pathology or anatomy. The conflict is being from whether it is an undergraduate, postgraduate. ${ }^{17-19}$ In those institutes in which it is well recognized and established, in the undergraduate curriculum, the subject areas and the teaching strategies are subjects of inquiry in addition to some subjects that may be the source of conflicts with the dermatology course. $^{20}$ The debate continues about what should be delivered in the organization of undergraduate course. ${ }^{21,22}$

Up till now, in plastic surgery, there is no data about integration with dermatology course at the undergraduate level, but the integration of plastic surgery with general surgery is present in some medical schools at residency level. $^{22,23}$ The main idea of the integration between dermatology and plastic surgery comes from the collections of area of similarities and dissimilarities between the two branches as a form of interdisciplinary integration.

Albaha University Faculty of Medicine (ABSM) is adopting an integrated system-based curriculum. In the basic sciences and clinical phases, integration was direct and system-based, somewhat interdisciplinary in some courses. ${ }^{24-27}$

In ABSM, dermatology and plastic surgery were taught in the fifth year in a clinical module of 3 weeks and three credit units. This module is preceded by a basic integumentary course in the second year (three credit units). The aim of the basic module is to teach the students the structure and functions of the integument which will facilitate easy understanding of skin pathologies and treatment.

In this paper, we will describe how we integrate teaching dermatology and plastic surgery in one module as a form of interdisciplinary integration for our undergraduate medical students at ABSM.

\section{Material and methods}

The committee was formulated by vice-deanship for quality and development affairs and documented from faculty deanship and the deanship of the institute; the committee consisted of staff members of dermatology, plastic surgery, general surgery, community physician, pathology, pharmacology, medical education and representatives from administration of faculty to facilitate the logistic material needed for implementation of the module. Also, the committee includes representatives from the other basic sciences department as anatomist, biochemist and physiologist. The function of the committee was how to integrate both dermatology and plastic surgery as interdisciplinary forms of integration. Several registered workshops were done to design the course 
and put the teaching strategy and selecting the appropriate teaching tools to be suitable with the students learning style and achieve the objectives applied.

A cross-sectional study was done using a well structured, valid and reliable questionnaire. The questionnaire was designed to estimate the needs for the interdisciplinary integration; high level of integration as described by Harden. $^{28}$ The questionnaire was designed by the medical education unit that follows the quality and development affairs of ABSM. The questionnaire focused to clarify the opinions of all school staff members about the dermatology-plastic surgery integration.

The questionnaire was subjected to test for validity by insertion of short cohort study on a small number of school staff with different disciplines. The analysis of this short cohort proved the reliability of the questionnaire. In addition, the results obtained ensured the needs of the school for the designation and implementation of dermatologyplastic surgery interdisciplinary course. These results motivate the module committee to follow the upcoming steps for establishing the process of the course development.

\section{Formation and judgment of ILOs}

The module committee did several meetings to put the basic rules for the formulation of learning objectives. These roles subjected to the steps were first described by Kern et al. ${ }^{29}$ The 6 Kern' steps include:

Step 1: Problem identification/General Needs Assessment; Step 1 starts with the identification and analysis of a health care need or other problem that is to be addressed by the curriculum. Clear definition of the problem helps to focus a curriculum's goal and objectives which in turn help to focus the curriculum's educational and evaluation strategies. A comprehensive definition of the problem includes consideration of epidemiology, impact on patients, health care professionals and society.

Step 2: Needs assessment of targeted learners; A needs assessment of targeted learners is a process by which the curriculum developers identify the differences between the ideal and actual characteristics of the targeted learner group, and their environment identify targeted learners. Methods for learner needs assessment include informal discussions/ formal interviews, focus group discussions, questionnaires, direct observation of skills, examinations, audits of current performance and strategic planning session.

Step 3: Goals and Objectives; After the needs of learners have been clarified, the curriculum is targeted to address these needs by setting goals and objectives. A goal or objective is defined as an end toward which an effort is directed. ${ }^{30}$ Goal is a broad educational objective or a directive. It communicates the overall purposes of the curriculum while the objective is more specific educational directive that is usually stated behaviorally, ie, it is measurable.

Step 4: Educational Strategies; Once the goals and objectives are determined, the next step is to develop educational strategies. It includes designation of both content and method of delivery. The content is the specific material to be included in the curriculum while the methods are the ways in which content is presented. The content of the curriculum flows from its specific measurable objectives.

Step 5: Implementation; this step comprises the Identification of resources needed; Personnel: faculty, secretarial/administrative support, patients. Time: faculty, support staff, learners. Facilities: space, equipment, clinical sites. Funding/costs: direct financial costs, hidden or opportunity costs. Beside resources the support is highly needed, which obtained either from Internal; from an administrative authority (dean's office, hospital administration, department chair, program director, faculty, learners, other stakeholders for personnel, resources, political support or outside from government, professional societies, managed care, donors for funding, political support, curricular or faculty development resource

Step 6: Evaluation and Feedback; This step closes the loop in the curriculum development cycle and provides information to guide individuals and the curriculum in cycles of improvement. Evaluation results can be used to seek support for curriculum, assess individual achievement, satisfy external requirements and serve as a basis for presentations and publications.

\section{Application of the Kern' steps in the current integrated dermatology and plastic surgery course}

The first step is the identification of the problems and assessment of the current needs and the identification of gaps (step 1 and 2). As ABSM is a community-based school, the module committee made several visits to dermatology and plastic surgery units (wards and outpatient clinic) of Albaha province hospitals including primary, secondary and tertiary hospitals. The aim of these visits was to stand on the wide varieties of common dermatological diseases and common fields in the plastic surgery that 
needs to be addressed and prioritized in the course. The committee members were given a permissive access to the patients' files in the record unit. These members listed the major health problems as well as the management protocols applied. Analysis of the data obtained revealed a list of the diseases that have to be heavily addressed and prioritized in the course. From this list, the goals and learning objectives were designed (step 3) according to the SMART criteria. These ILOs were subjected to open discussion with all staff members involved in the teaching and learning process. Finally, a further analysis and refinement of the ILOs occurred by the staff member of the medical education unit.

The upcoming step is to how to select the appropriate teaching strategy and tool for each learning objective (step 4). The student-centered tools such as PBL, SDL and seminars were prioritized. In addition, interactive lectures which depend on audio-video, role-play, small group discussion, open discussion, explanations and periodic summaries were also addressed. Furthermore, hospital-based teaching and skill lab teaching for acquisitions of skills have been selected. The subject areas and their teaching tools are formulated in Table 1.

The implementation of the module (step 5) went smooth as planned by the module committee. The implementation took place in three facilities. The college building, in which all lectures, seminars, skill laboratory sessions and PSSs took place. The primary health care centers, where students visit to attend special skin care clinics. These clinics, in our settings, were run by family physicians. The third facility is the three relatively large regional hospitals in the area. One of these hospitals is a tertiary hospital with a large dermatology and plastic unit in addition to busy outpatient clinics. The students are divided into two groups to attend activities related to the dermatology alternating with plastic surgery activities. There are some commonalities and similarities joined both the academic and training activities of the dermatology and plastic surgery. Due to the paucity of the human resources in both dermatology and plastic surgery in ABSM, part of the clinical training and teaching is carried by consultants in the hospital. These consultants who belong basically in ministry of health were oriented about the module objectives and the committee signed with them a shortterm contract on a part-time basis.

The last step is the student assessment and course evaluation (step 6): A cognitive assessment was done through a well-constructed written exam (quiz and final exam) which encompasses wide varieties of assessment tools. These questions were designed to measure all levels of depth of knowledge and include multiple choices, extended matching, case scenario-based and short essay. Psychomotor assessment has been done through a wellstructured OSCE, which contain a dynamic station to assess the professionalism beside the other station specified to assess the communication skills among the students.

Course evaluation was to evaluate the course; the course evaluation was done using a Likert scale to assess the degree of satisfaction among the students and staff. The questionnaire was mainly quantitative with small area for qualitative evaluation in which the students can write comments and recommendations. The questionnaire was utilized by the 150 students representing the last 4 year iterations.

A non-parametric test as independent $t$-test was used to analyze the results of questionnaires in the present work.

\section{Results}

\section{Problem identification/general needs assessment (step I and 2)}

After doing several visits to dermatology and plastic surgery units (wards and outpatient clinic) and meeting with the stakeholders of Albaha province hospitals including primary, secondary and tertiary hospitals, we found some major conflicts between both dermatology and plastic surgery unit and major plans have to be addressed to solve these conflicts; of these, needs for integrating dermatology and plastic surgery into one course as interdisciplinary one. Also, the questionnaire applied for recognizing the needs and for course design among 50 staff members regarding the dermatology and plastic surgery course revealed the following: staff showed strongly satisfaction was $35 ; 70 \%$, satisfied; $6 ; 12 \%$, neutral; $4 ; 8 \%$, dissatisfied; $3 ; 6 \%$ and strongly dissatisfied $2 ; 4 \%$ with significant $P$-value obtained $(P$-value $=0.0021)($ Table 2 and Figure 1$)$.

\section{Regarding need assessment step (step 2)}

Analysis of the gap between the current and desired needs revealed a shortage in some infrastructures and staff members, especially of plastic surgery. These problems were resolved by doing partnerships with some primary and secondary hospitals in the Albaha province.

\section{Regarding goals and objectives (step 3)}

The 4-year-questionnaire applied to estimate the satisfaction of both students and staff regarding goals and objectives 
Table I Teaching strategies of the dermatology and plastic surgery course

\begin{tabular}{|c|c|c|c|}
\hline Theme & Objectives/topics & Method of instruction & Assessment \\
\hline $\begin{array}{l}\text { Dermatology } \\
\text { Acne vulgaris }\end{array}$ & $\begin{array}{l}\text { Papulosquamous disease } \\
\text { Lecture } \\
\text { Eczema } \\
\text { Urticaria and angioedema } \\
\text { Bacterial skin diseases } \\
\text { Introduction to the skin diseases } \\
\text { Parasitic infection of the skin } \\
\text { Fungal skin diseases } \\
\text { Viral skin diseases } \\
\text { Severe and life-threatening skin conditions (Steven-Johnson, } \\
\text { erythema, toxic epidermal necrolysis) }\end{array}$ & $\begin{array}{l}\text { Lecture/clinical teaching } \\
\text { MCQs } \\
\text { Lecture/clinical teaching } \\
\text { Lecture/clinical teaching } \\
\text { Lecture/seminar } \\
\text { Lecture } \\
\text { Lecture/seminar } \\
\text { Lecture/clinical teaching } \\
\text { Lecture/seminar } \\
\text { Lecture/seminar/skill laboratory }\end{array}$ & $\begin{array}{l}\text { MCQs/OSCE } \\
\text { MCQs } \\
\text { MCQs } \\
\text { MCQs/CW } \\
\text { MCQs } \\
\text { MCQs/CW } \\
\text { MCQs } \\
\text { MCQs/short } \\
\text { assay } \\
\text { MCQs/OSCE/ } \\
\text { CW }\end{array}$ \\
\hline Plastic surgery & $\begin{array}{l}\text { Congenital anomalies related to plastic surgery } \\
\text { The principle of plastic surgery (graft and flap) } \\
\text { Introduction to aesthetic plastic surgery } \\
\text { Cleft lip and palate } \\
\text { Hand tumors } \\
\text { Initial evaluation of injured hand } \\
\text { Hand infections } \\
\text { Keloid and hypertrophic scar } \\
\text { Burns } \\
\text { History and examination of skin disease } \\
\text { Skin biopsy } \\
\text { Laser } \\
\text { Suture materials and suture techniques }\end{array}$ & $\begin{array}{l}\text { Lecture } \\
\text { Lecture/skill laboratory } \\
\text { Lecture } \\
\text { Lecture } \\
\text { Lecture } \\
\text { Lecture/clinical teaching } \\
\text { Lecture } \\
\text { Lecture/clinical teaching } \\
\text { Lecture/seminar/clinical teaching } \\
\text { Skill laboratory/clinical teaching } \\
\text { Skill laboratory } \\
\text { Lecture/Skill laboratory } \\
\text { Skill laboratory }\end{array}$ & $\begin{array}{l}\text { MCQs } \\
\text { MCQs/OSCE } \\
\text { MCQs } \\
\text { MCQs/OSCE } \\
\text { MCQs } \\
\text { MCQs/OSCE } \\
\text { MCQs/OSCE } \\
\text { MCQs/OSCE } \\
\text { MCQs/OSCE/ } \\
\text { CW } \\
\text { OSCE } \\
\text { OSCE } \\
\text { MCQs/OSCE } \\
\text { OSCE }\end{array}$ \\
\hline $\begin{array}{l}\text { Dermatology and } \\
\text { plastic surgery }\end{array}$ & Skin tumors & $\begin{array}{l}\text { Lecture/seminar/skill labora- } \\
\text { tory/clinical teaching }\end{array}$ & $\begin{array}{l}\text { MCQs/OSCE/ } \\
\mathrm{CW}\end{array}$ \\
\hline General medicine & $\begin{array}{l}\text { Tropical dermatology } \\
\text { Skin manifestations of systemic diseases }\end{array}$ & $\begin{array}{l}\text { Lecture } \\
\text { PSS }\end{array}$ & $\begin{array}{l}\text { MCQs } \\
M C Q s / C W\end{array}$ \\
\hline General surgery & $\begin{array}{l}\text { Leg ulcers } \\
\text { Lymphedema }\end{array}$ & $\begin{array}{l}\text { Lecture } \\
\text { Lecture }\end{array}$ & $\begin{array}{l}\text { MCQs/OSCE } \\
\text { MCQs }\end{array}$ \\
\hline Others & $\begin{array}{l}\text { Dermatopharmacology } \\
\text { Skin manifestations of pediatrics diseases } \\
\text { Rheumatologic diseases and skin } \\
\text { Impetigo } \\
\text { Hair and nail disorder } \\
\text { Sexually transmitted diseases } \\
\text { Skin and subcutaneous lesions }\end{array}$ & $\begin{array}{l}\text { Lecture } \\
\text { Lecture } \\
\text { PSS } \\
\text { Lecture } \\
\text { PSS } \\
\text { SDL } \\
\text { SDL }\end{array}$ & $\begin{array}{l}\text { MCQs } \\
\text { MCQs } \\
\text { MCQs/CW } \\
\text { MCQs } \\
\text { MCQs/CW } \\
\text { MCQs/CW } \\
\text { MCQs/CW }\end{array}$ \\
\hline
\end{tabular}

Abbreviations: CW, coursework; MCQs, muliple choice questions; PSS, practical skill sessions; OSCE, objective structured clinical exam; SDL, self-directed learning.

(step 3) revealed the following: students who showed strongly satisfaction were $77 ; 51 \%$, satisfied; $43 ; 28 \%$, neutral; $8 ; 5.3 \%$, dissatisfied; $12 ; 8 \%$ and strongly dissatisfied $10 ; 6.6 \%$ with significant $P$-value obtained ( $P$-value $=0.003$ ) (Table 2 and Figure 1). The questionnaire applied for recognizing the staff satisfaction revealed the following: staff who showed strongly satisfaction were $36 ; 72 \%$, satisfied; $8 ; 16 \%$, neutral; $2 ; 4 \%$, dissatisfied; $2 ; 4 \%$ and strongly dissatisfied 2 ; $4 \%$ with significant $P$-value obtained ( $P$-value $=0.003)$. No significant difference was obtained between the student and staff satisfaction regarding goals and objective results with $P=0.0246$ (Table 2 and Figure 1). 
Table 2 Results of all questionnaires used to identify the degree of satisfactions among the students and staff in the present study

\begin{tabular}{|c|c|c|c|c|c|c|c|c|}
\hline Kern' steps & No. & Target & $\begin{array}{l}\text { Strongly } \\
\text { satisfied }\end{array}$ & Satisfied & Neutral & Dissatisfied & $\begin{array}{l}\text { Strongly } \\
\text { dissatisfied }\end{array}$ & $\begin{array}{l}\text { Independent } \\
\text { t-test }\end{array}$ \\
\hline $\begin{array}{l}\text { Step I\& 2: Needs } \\
\text { assessment }\end{array}$ & 50 & Staff & $35 ; 70 \%$ & $6 ; 12 \%$ & $4 ; 8 \%$ & $3 ; 6 \%$ & $2 ; 4 \%$ & \\
\hline $\begin{array}{l}\text { Step 3: Goals and } \\
\text { objectives }\end{array}$ & $\begin{array}{l}150 \\
50\end{array}$ & $\begin{array}{l}\text { Students } \\
\text { Staff }\end{array}$ & $\begin{array}{l}77 ; 51 \% \\
36 ; 72 \%\end{array}$ & $\begin{array}{l}43 ; 28 \% \\
8 ; 16 \%\end{array}$ & $\begin{array}{l}8 ; 5.3 \% \\
2 ; 4 \%\end{array}$ & $\begin{array}{l}12 ; 8 \% \\
2 ; 4 \%\end{array}$ & $\begin{array}{l}10 ; 6.6 \% \\
2 ; 4 \%\end{array}$ & $P=0.0246$ \\
\hline $\begin{array}{l}\text { Step 4: Educational } \\
\text { strategies }\end{array}$ & 150 & Students & $65 ; 43.3 \%$ & $33 ; 22 \%$ & $12 ; 8 \%$ & $16 ; 10.6 \%$ & $24 ; 16 \%$ & $P=0.0224$ \\
\hline $\begin{array}{l}\text { Step 5: } \\
\text { Implementation }\end{array}$ & $\begin{array}{l}50 \\
150\end{array}$ & $\begin{array}{l}\text { Staff } \\
\text { Students }\end{array}$ & $\begin{array}{l}30 ; 60 \% \\
47 ; 31.3 \%\end{array}$ & $\begin{array}{l}8 ; 16 \% \\
43 ; 28.6 \%\end{array}$ & $\begin{array}{l}4 ; 8 \% \\
15 ; 10 \%\end{array}$ & $\begin{array}{l}5 ; 10 \% \\
30 ; 20 \%\end{array}$ & $\begin{array}{l}3 ; 6 \% \\
15 ; 10 \%\end{array}$ & $P=0.0008$ \\
\hline $\begin{array}{l}\text { Step 6: Course } \\
\text { evaluation }\end{array}$ & $\begin{array}{l}50 \\
150 \\
50\end{array}$ & $\begin{array}{l}\text { Staff } \\
\text { Students } \\
\text { Staff }\end{array}$ & $\begin{array}{l}28 ; 56 \% \\
80 ; 53.3 \% \\
29 ; 58 \%\end{array}$ & $\begin{array}{l}12 ; 24 \% \\
32 ; 21.3 \% \\
8 ; 16 \%\end{array}$ & $\begin{array}{l}4 ; 8 \% \\
18 ; 12 \% \\
3 ; 6 \%\end{array}$ & $\begin{array}{l}4 ; 8 \% \\
\text { II; } 7.3 \% \\
6 ; 12 \%\end{array}$ & $\begin{array}{l}2 ; 4 \% \\
9 ; 6 \% \\
4 ; 8 \%\end{array}$ & $P=0.4361$ \\
\hline
\end{tabular}

Note: Bold values indicate statistical significance. ${ }^{*}$ The result is not significant at $P<0.05$.

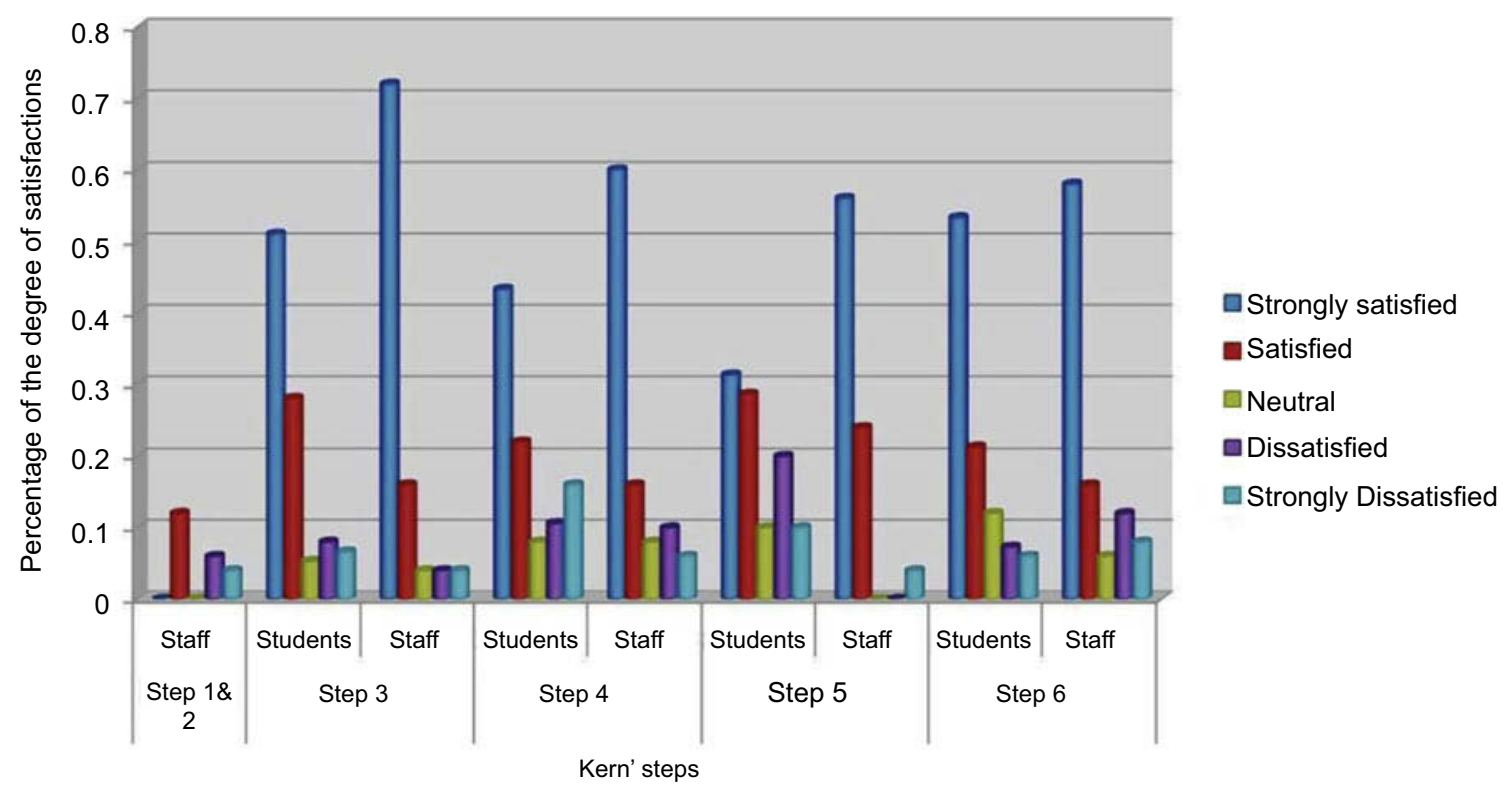

Figure I Summary of the results of the questionnaires used for both staff and student in the present work.

\section{For educational strategies (step 4)}

The results of questionnaire applied to estimate the degree of satisfaction about the educational strategies revealed the following: students who showed strongly satisfaction were $65 ; 43.3 \%$, satisfied; $32 ; 22 \%$, neutral; $12 ; 8 \%$, dissatisfied; $16 ; 10.6 \%$ and strongly dissatisfied $24 ; 16 \%$. The questionnaire applied for recognizing the staff satisfaction revealed the following: staff who showed strongly satisfaction was $30 ; 60 \%$, satisfied; $8 ; 16 \%$, neutral; $4 ; 8 \%$, dissatisfied; $5 ; 10 \%$ and strongly dissatisfied $3 ; 6 \%$ with significant $P$-value obtained between the students and staff' satisfaction $(P$-value $=0.0224)($ Table 2 and Figure 1$)$.

\section{Regarding the implementation step (step 5)}

The students and staff' satisfaction about the mode of module implementation revealed the following: students who showed strongly satisfaction were $47 ; 31.3 \%$, satisfied; $43 ; 28.6 \%$, neutral; $15 ; 10 \%$, dissatisfied; $30 ; 20 \%$ and strongly 
dissatisfied $15 ; 10 \%$. The questionnaire applied for recognizing the staff satisfaction revealed the following: staff who showed strongly satisfaction were $28 ; 56 \%$, satisfied; 12 ; $24 \%$, neutral; $4 ; 8 \%$, dissatisfied; $4 ; 8 \%$ and strongly dissatisfied 2; 4\%. No significant difference was obtained between the student and staff satisfaction regarding mode of implementation with $P$-value $=0.0008$ (Table 2 and Figure 1).

\section{Regarding course evaluation (step 6)}

The course evaluation revealed the following: students who showed strongly satisfaction were $80 ; 53.3 \%$, satisfied; 32 ; $21.3 \%$, neutral; $18 ; 12 \%$, dissatisfied; $11 ; 7.3 \%$ and strongly dissatisfied $9 ; 6 \%$. The questionnaire applied for recognizing the staff satisfaction revealed the following: staff who showed strongly satisfaction was $29 ; 58 \%$, satisfied; 8 ; $16 \%$, neutral; $3 ; 6 \%$, dissatisfied; $6 ; 12 \%$ and strongly dissatisfied $4 ; 8 \%$. No significant difference was obtained between the student and staff satisfaction regarding course evaluation with $P=0.4361$ (Table 2 and Figure 1).

Differential analysis for dermatology and plastic surgery courses in the current integrated course revealed a significant difference between the student and staff' satisfaction about the goals and objectives of plastic surgery course with $P$-value $=0.150$. In implementation step, there is also a significant difference between the student and staff' satisfaction about implementation of dermatology course with $P$-value $=0.0086$. The course evaluation for dermatology course revealed a significant difference in the students and staff satisfaction with $P$-value $=0.006$. More details for assessing the dermatology and plastic surgery courses in a separate manner are illustrated in Table 3 and Figure 2.

\section{Discussion}

Dermatological problems are a growing health system problem and the number of patients with skin diseases is increasing, this requires that medical school should adapt their curricula to equip their graduates with necessary theoretical and clinical competencies to deal with this issue. ${ }^{6,7}$

Medical students regrettably achieve limited experience to both dermatology and plastic surgery, usually within the fourth or fifth year of medical studies, but the length of exposure varies around the medical schools and ranging from 1 to 3 weeks. This time is not enough at all to acquire a solid knowledge of the dermatology. ${ }^{8-10}$

There are insufficient data and limited information about the experiences of medical school about the integration of both dermatology and plastic surgery as an interdisciplinary course. This motivates us to expose our 4-year experience in an attempt to make reciprocal relationship with other schools depending on their response.

One of the most important interventions that we did in our medical school in Albaha to save time is to mix similar courses. $^{25,27}$ In our school, we merge dermatology and plastic surgery courses in one module. We did not come across

Table 3 results of all questionnaires used for estimation of the degree of satisfactions among the students and staff for dermatology and plastic surgery courses in the current integrated dermatology/plastic surgery module

\begin{tabular}{|c|c|c|c|c|c|c|}
\hline \multirow[t]{2}{*}{ Kern' steps } & \multirow[t]{2}{*}{ Course } & \multicolumn{2}{|l|}{ Students } & \multicolumn{2}{|l|}{ Staff } & \multirow{2}{*}{$\begin{array}{l}\text { Independent } \\
\text { t-test }\end{array}$} \\
\hline & & Satisfied & Dissatisfied & Satisfied & Dissatisfied & \\
\hline \multirow[t]{3}{*}{ Step 3: Goals and objectives } & Dermatology & $126 ; 84 \%$ & $6 ; 4 \%$ & $43 ; 86 \%$ & $3 ; 6 \%$ & $P$-value $=0.313$ \\
\hline & Plastic surgery & $117 ; 78 \%$ & $15 ; 10 \%$ & $44 ; 88 \%$ & $\mathrm{I} ; 2 \%$ & $P$-value $=0.0150$ \\
\hline & \multicolumn{3}{|l|}{$P$-value $=0.0688$} & \multicolumn{3}{|c|}{$P$-value $=0.317$} \\
\hline \multirow[t]{3}{*}{ Step 4: Educational strategies } & Dermatology & $110 ; 73.3 \%$ & $18 ; 12 \%$ & $41 ; 82 \%$ & $5 ; 10 \%$ & $P$-value $=0.512$ \\
\hline & Plastic surgery & $106 ; 70.6 \%$ & $22 ; 14.6 \%$ & $37 ; 74 \%$ & $3 ; 6 \%$ & $P$-value $=0.0729$ \\
\hline & \multicolumn{3}{|l|}{$P$-value $=0.491 \mathrm{I}$} & \multicolumn{3}{|c|}{$P$-value $=0.5915$} \\
\hline \multirow[t]{3}{*}{ Step 5: Implementation } & Dermatology & $110 ; 73.3 \%$ & $29 ; 19.3 \%$ & $40 ; 80 \%$ & $3 ; 6 \%$ & $P$-value $=0.0086$ \\
\hline & Plastic surgery & $86 ; 57.3 \%$ & $16 ; 10.6 \%$ & $40 ; 80 \%$ & $3 ; 6 \%$ & $P$-value $=0.110$ \\
\hline & \multicolumn{3}{|l|}{$P$-value $=0.308$} & \multicolumn{3}{|l|}{$P$-value $=I$} \\
\hline \multirow[t]{3}{*}{ Step 6: Course evaluation } & Dermatology & $116 ; 77.3 \%$ & $4 ; 2.6 \%$ & $31 ; 62 \%$ & $4 ; 8 \%$ & $P$-value $=0.0718$ \\
\hline & Plastic surgery & $107 ; 71.3 \%$ & $16 ; 10.6 \%$ & $28 ; 56 \%$ & $6 ; 12 \%$ & $P$-value $=0.4738$ \\
\hline & \multicolumn{3}{|l|}{$P$-value $=0.006$} & \multicolumn{3}{|c|}{$P$-value $=0.4631$} \\
\hline
\end{tabular}

Note: Bold values indicate statistical significance. ${ }^{*}$ The result is not significant at $P<0.05$. 


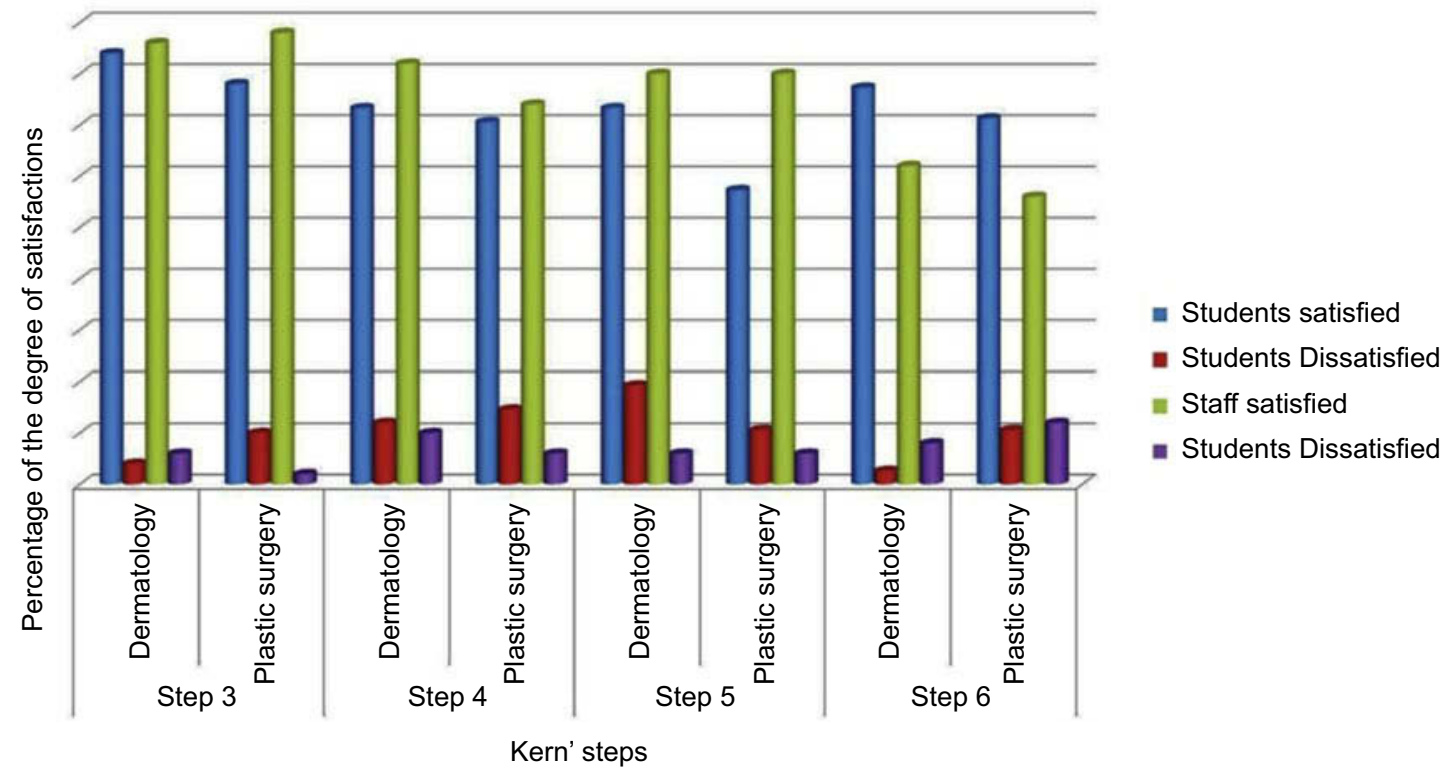

Figure 2 Results of questionnaires regarding dermatology and plastic surgery course in the integrated dermatology and plastic surgery course.

similar experience in the literature, but Hoey in 2012 stated that both dermatology and plastic surgery are delivering integrated services. ${ }^{8}$ Delivering integrated services in the practice opens a door for us to integrate both disciplines at the teaching level. In practice, there are a lot of overlaps between dermatology and plastic surgery, especially in the field of treatments, such as skin cancers and laser therapy. ${ }^{9}$ In our model, we utilize this overlaps down at the level of teaching and training. Plastic surgeons are like dermatologists, they operate throughout the body, treating the widest range of trauma, malignancy and congenital diseases. Both disciplines deal with a broad spectrum of sensitive, emotional and psychological issues such as cancer diagnosis, reconstruction following disfiguring cancer and/or trauma surgery as well as difficult esthetic issues. ${ }^{6}$

The 4-year course evaluation revealed the student satisfaction was $86 \%$. These results matched with the 3 -year evaluation of pathology and radiology integration done in the same school by Atta et $\mathrm{al}^{27}$. Collection of the similarities among disciplines is being addressed in the same session which resulted in more understanding and knowledge acquisition. This, in turn, reflects the psychological aspect of the students as that obtained by Atta et al who searched the learning style of students in ABSM and revealed that $>90 \%$ have a visual learning style. ${ }^{31,32}$ This observation is confirmed by the study of radiology teaching by Alqahtani. ${ }^{33}$ Also, it is in agreement with the Gestalt principles ${ }^{34}$ which demonstrated how the eye perceives visual elements distinctively; the complex images tend to be simplified shapes. In addition, it coincides with many derivatives elaborated from Gestalt theory, such as laws of closure, the figure-attached relationship and diversity of grouping principles such as similarity common region, continuity, proximity and symmetry.

\section{Conclusion}

Although it is a difficult task to merge the two disciplines and integrate them in the system-based medical curriculum, it is achievable with good planning and good teamwork. The faculties and students raised significant points in the feedback which will help in the current evaluation of this module and guide the improvement measures in the future implementation.

\section{Disclosure}

The author reports no conflicts of interest in this work.

\section{References}

1. Hansra NK, O'Sullivan P, Chen CL, Berger TG. Medical school dermatology curriculum: are we adequately preparing primary care physicians? J Am Acad Dermatol. 2009;61:23-29. doi:10.1016/j. jaad.2008.11.912

2. Davila M, Christenson LJ, Sontheimer RD. Epidemiology and outcomes of dermatology in-patient consultations in a Midwestern U.S. University hospital. Dermatol Online J. 2010;16:12.

3. Kirshen C, Shoimer I, Wismer J, DesGroseilliers JP, Lui H. Teaching dermatology to Canadian undergraduate medical students. J Cutan Med Surg. 2011;15:150-156. doi:10.2310/7750.2011.10021

4. Chi CC. Evidence-based dermatology. Dermatol Sin. 2013;31:2-6. doi:10.1016/j.dsi.2012.06.002 
5. Burge S. Teaching dermatology to medical students: a survey of current practice in the UK. Br J Dermatol. 2002;146:295-303.

6. Fleischer AB, Feldman SR, Rapp SR. Introduction. The magnitude of skin disease in the United States. Dermatol Clin. 2000;18:xv-xxi.

7. Aman S, Nadeem M, Mahmood K, Ghafoor MB. Pattern of skin diseases among patients attending a tertiary care hospital in Lahore, Pakistan. J Taibah Univ Sci. 2017;12:392-396.

8. Hoey S. So you want to be a dermatologist. Ulster Med J. 2012;81:172.

9. Ross EV, Barnette DJ, Glatter RD, Grevelink JM. Effects of overlap and pass number in $\mathrm{CO}_{2}$ laser skin resurfacing: a study of residual thermal damage, cell death, and wound healing. Lasers Surg Med. 1999;24:103-112.

10. Au A, Kim JB. Integration of plastic surgery into the undergraduate medical curriculum: the Norwich model and experience. Int $\mathrm{J} \mathrm{Med}$ Educ. 2012;3:14-16. doi:10.5116/ijme.4f0c.b55b

11. Alharethy SE. Trends and demographic characteristics of Saudi cosmetic surgery patients. Saudi Med J. 2017;38:738-741. doi:10.15537/ smj.2017.7.18528

12. Al-Dawsari NA, Amra N. Pattern of skin cancer among Saudi patients attending a tertiary care center in Dhahran, Eastern Province of Saudi Arabia. A 20-year retrospective study. Int J Dermatol. 2016;55:1396-1401. doi:10.1111/ijd.13320

13. Chęś A. The middle eastern market of cosmetics and toiletries: characteristics underlying demand and potential for growth Studia ekonomiczne. Cent Eur J Soc Sci Human. 2016;7:114-133.

14. Ben-Shabat H, Kassack J, Moriarty M, et al. The 2015 global retail development Index ${ }^{\mathrm{TM}}$. Global retail expansion: an unstoppable force 2015. Available from: http://www.atkearney.com. Accessed June 15, 2015.

15. Von Soest T, Kvalem I, Skolleborg K, Roald H. Psychosocial factors predicting the motivation to undergo cosmetic surgery. Plast Reconstr Surg. 2006;117:51-62.

16. Markey AC. Dermatologists and cosmetic surgery-a personal view of regulation and training issues. Clin Exp Dermatol. 2004;29 (6):690-692. doi:10.1111/j.1365-2230.2004.01640.x

17. Wright V, Hopkins R, Burton KE. What shall we teach undergraduates? BMJ. 1979;1(6166):805-807.

18. McGrouther DA. All doctors need plastic surgery. Br J Hosp Med. 1993;49(2):137.

19. Rowsell AR. The place of plastic surgery in the undergraduate surgical curriculum. Br J Plast Surg. 1986;39(2):241-243.

20. Prater MA, Smith DJ. Determining undergraduate curriculum content in plastic surgery. Plast Reconstr Surg. 1989;84(3):529-533.

21. Porter JM, Rayner CR, Fenton OM. Teaching plastic surgery to medical students. Med Educ. 1992;26(1):42-47.
22. Burda A, Chiua T, McNaught C. Plastic surgery in the undergraduate curriculum: the importance of considering students' perceptions. Br Ass Plast Surg. 2004;57:773-779. doi:10.1016/j. bjps.2004.05.017

23. Luce EA. The future of plastic surgery resident education. Plast Reconstr Surg. 2016;137(3):1063-1070. doi:10.1097/01. prs.0000479982.67922.8a

24. Elfakey WE, Koshak EA, Abdelaziz A, et al. Evaluation of a multidisciplinary clinical module on cardiology and cardiovascular surgery at Al-Baha University: students and academic staff perceptions. Educ Med J. 2015;7:27-34.

25. Elfakey WE, Al-Ghamdi AH. Ten steps to plan, design, and implement an endocrinology and endocrine surgery module for the Faculty of Medicine, Al-Baha University. Adv Med Educ Pract. 2016;7:617-622. doi:10.2147/AMEP.S113144

26. Atta IS. AlQahtani FN Matching medical student achievement to learning objectives and outcomes: a paradigm shift for an implemented teaching module. Adv Med Educ Pract. 2018;9:227-233. doi:10.2147/AMEP.S158784

27. Atta IS, AlQahtani FN. Integrated pathology and radiology learning for a musculoskeletal system module: an example of interdisciplinary integrated form. Adv Med Educ Pract. 2018;9:527-533. doi:10.2147/ AMEP.S167692

28. Harden RM, Sowden S, Dunn WR. Educational strategies in curriculum development: the SPICES model. Med Educ. 1984;18 (4):284-297.

29. Kern DE, Thomas PA, Howard DM, Bass EB, editors. Curriculum Development for Medical Education: A Six-Step Approach. Baltimore (MA): The Johns Hopkins University Press Center; 1998.

30. Benjamin SB, Krathwohl DR. Taxonomy of Educational Objectives: The Classification of Educational Goal, by a Committee of College and University Examiners. New York (NY): Longmans; 1956.

31. Atta IS, Alqahtani FN. How to adjust the strategy of radiopathologic teaching to achieve the learning outcomes? Int J Med Sci Public Health. 2018;7:1130015122017.

32. Atta IS, Alqahtani FN, Alghamdi TA, Mankrawi SA, Alamri AM. Can pathology - teaching' strategy be affected by the students' learning style and to what extent the students' performance be affected? Glo Adv Res J Med Med Sci. 2017;6 (11):296-301.

33. Alqahtani FN. Radiology learnining or teaching subject area vs. modalities: students' perspectives and experience in Albaha university. Adv Med Educ Pract. 2018;9:791-799. doi:10.2147/AMEP.S171977

34. Koffka K. Principles of Gestalt Psychology. London: Routledge; 1935:176.
Advances in Medical Education and Practice is an international, peerreviewed, open access journal that aims to present and publish research on Medical Education covering medical, dental, nursing and allied health care professional education. The journal covers undergraduate education, postgraduate training and continuing medical education including emerging trends and innovative models linking education, research, and health care services. The manuscript management system is completely online and includes a very quick and fair peer-review system. Visit http://www.dovepress.com/testimonials.php to read real quotes from published authors. 